\title{
Pharmaciana
}

Vol.8, No.2, Nov 2018, Page. 267-274

ISSN: 2088 4559; e-ISSN: 24770256

DOI: $10.12928 /$ pharmaciana.v8i2.10573

\section{Evaluation of adherence, distress and quality of life for type 2 diabetes melitus patients In Puskesmas Wedarijaksa I and Puskesmas Trangkil Kabupaten Pati}

\author{
Diah Aryani Perwitasari ${ }^{1}$, Siti Urbayatun ${ }^{2}$, Oni Yulianta Wilisa ${ }^{* 3}$ \\ ${ }^{1}$ Faculty of Pharmacy Universitas Ahmad Dahlan \\ ${ }^{3}$ Pharmacy Postgraduate Universitas Ahmad Dahlan \\ Jl. Prof. Dr. Soepomo,S.H,Yogyakarta \\ ${ }^{2}$ Faculty of Psikology Universitas Ahmad Dahlan \\ Jl.Kapas 9, Semaki, Yogyakarta
}

Submitted: 16-07-2018

Reviewed: 09-10-2018

Accepted: 06-11-2018

\begin{abstract}
Diabetes mellitus is chronic disease that needs the complex and a long term medical treatment. Patient adherence and level of distress can affect patient quality of life. The purposes of this study is to examine patients adherence, distress, and quality of life patients type 2 diabetes mellitus in Kabupaten Pati. This study used cross sectional design and data patients collection techniques were conducted prospective data. The subjects of research were patients with Type 2 diabetes amounted to 126 people. Instruments used in this research is Medication Adherence Respon Scale (MARS) questionnaire to measure patients adherence, Diabetes Distress Scale (DDS) to measure distress, and EQ-5D-5L questionnaire to measure quality of life. Data analysis statistic used Mann Whiney test, and linier regression. This study was dominated by female patients $78.6 \%$. The mean age of DMT2 patients was $54.49 \pm 6.19$ years. The average value of adherence (MARS) was $21.33 \pm 2.90$ including in moderate adherence. The mean total of DDS score was 1,56 $\pm 0,42$ including not distress level and the highest is the emotional burden domain. The mean value of EQ5D5L index was $0.729 \pm 0.161$. The results showed a significant association $(\mathrm{p}<0.05)$ between patient characteristics age and duration of sick with adherence. There were significant association $(\mathrm{p}<0.05)$ between age to physician distress, gender with emotional, marital status with emotional and interpersonal distress, duration of sick to physician distress and management therapy distress. Marital status and income had significant relationship to quality of life. Emotional burden domain had significant relationship to quality of life. Multivariate analysis showed that the relationship of adherence and distress by the emotional burden to quality of life. This study concluded the significant relationship between adherence, distress and quality of life.
\end{abstract}

Keywords: type 2 DM, adherence, distress, quality of life

\footnotetext{
*Corresponding author:

Oni Yulianta Wilisa

Pharmacy Postgraduate, Universitas Ahmad Dahlan

Jl. Prof. Dr. Soepomo, S.H,Yogyakarta

Email: anta.wilisa@gmail.com
} 


\section{INTRODUCTION}

Diabetes mellitus is chronic disease that occurs when pancrease does not produce enough insulin or when the body does not effectively use the resulting insulin. Diabetes is the leading cause of death of 1,5 million people worldwide in 2012. International Diabetes Federation (IDF) predicts an increase in the number of people with diabetes in Indonesia from 9,1 million in 2014 to 14,1 million in 2035 (Perkeni, 2015). Increasing the number of people with diabetes due to various factors including the patients adherence in term of treatment. Cause of poor adherence are complex, including the complexity of treatment regimens, drug cost, age, low social support and cognitive problems (WHO, 2003). Rizkifani et al.(2014) reported that adherence of type 2 diabetes mellitus patients receiving monotherapy and combination of oral insulin antidiabetic therapy had moderate adherence of 23,54 .

Long term medical treatment of diabetes mellitus can affect emotional distress of diabetes mellitus patients. Permana (2017) show that patient who are sick more than 10 years, the level of distress of patients are mostly mild, while the components distress of the most dominant of the onset of distress to the patient is the emotional burden and response to health workers, and there is a relationship between a long illness at the level of distress in patients with diabetes mellitus ( $\mathrm{p}$-value $=$ 0.001) where the longer sick, the lower the level of distress.

Patients adherence level with distress or emotional can affect patients quality of life. Improve quality of life is characterized by free of complaints, normal body function, daily activities not disturbed, can be social functioning, and others (Spilker and Cramer, 1998). Pradana (2013) research about the quality of life of elderly patients in Dr. Karyadi Semarang shows the average of quality of life with EQ VAS $72,92 \pm 10,14$. Patients quality of life using EQ5D questionnaire show there are many problems with $1,9 \%$ mobility domain, $2,8 \%$ self care, $2,8 \%$ daily activity, and $0,9 \%$ depression.

Soegondo (2010) explain that the type of health services provided by Puskesmas to type 2 diabetes mellitus patients is primary health care, that is affordable, cheap, easy, practical health services, and appropriate with basic standard medication in Puskesmas. Based on description, it is necessary to evaluate adherence, distress and quality of life diabetes mellitus patients at Puskesmas Wedarijaksa I and Puskesmas Trangkil.

\section{MATERIALS AND METHODS}

The research was a cross sectional design in the treatment of type 2 diabetes mellitus patients at Puskesmas Wedarijaksa I and Puskesmas Trangkil in period August-November 2017. The subjects of research were patients with Type 2 diabetes amounted to 126 people. Instruments used in this research is Medication Adherence Report Scale (MARS) questionnaire to measure patients adherence, Diabetes Distress Scale (DDS) to measure distress, and EQ-5D-5L questionnaire to measure quality of life

MARS have five questions on a frequency scale of 1 to 5 (always, often, occasionally, rarely, and never) (Molloy et al., 2012). The DDS consist 17 questions in 4 domains, emotional burden, physician distress, regiment distress, and interpersonal distress. DDS have frequency scale of 1 of 6 . If the average total score of less than 2,0 indicates no pressure, score between 2,0-2,9 indicates moderate pressure, score of 3,0 or more indicates a level high pressure (Polonsky et al., 2005). The EQ-5D questionnaire consist of 6 items covering 5 health dimensions: mobility, self-care, regular activity, pain/discomfort, and anxiety/depression where each question has a value/score. The highest score is assigned of 1 and the lowest score is assigned a value of 5 (Horowitz et al., 2010).

Univariate analysis used proportion or average value. The bivariate analysis used MannWhitney test for two-group data . Multivariate analysis used multiple linear regression test. This study received ethical approval from the Research Ethics Committee of Universitas Ahmad Dahlan. 
RESULT AND DISCUSSION

Characteristics of patients with T2DM in Puskesmas Wedarijaksa I and Trangkil can be seen in Table I.

Table I. Patient distribution

\begin{tabular}{lll}
\hline Characteristics (n=126) & Mean \pm SD & \\
\hline Mean age (SD), year & $54,49 \pm 6,19$ & \\
Mean duration / duration of treatment of & $3,95 \pm 3,27$ & \\
T2DM (SD), year & & \\
\hline Characteristics (n=126) & & Persentase (\%) \\
\hline Gender (\%) & 27 & 21,4 \\
a. Male & 99 & 78,6 \\
b. Women & & \\
Education (\%) & 80 & 63,5 \\
a. Lower education & 46 & 36,5 \\
b. Higher education & & \\
Marital status (\%) & 7 & 5,6 \\
a. Single/widow/divorced & 119 & 94,4 \\
b. Married & & \\
Employment (\%) & 76 & 60,3 \\
a. Employed & 50 & 39,7 \\
b. Unemployed & & \\
Income & 114 & 90,5 \\
a. <Rp.1000.000 & 12 & 9,5 \\
b. >Rp.1000.000 & & \\
\hline
\end{tabular}

The results showed that the patient was dominated by female patients $(78.6 \%)$. The mean age of DMT2 patients was $54.49 \pm 6.186$. The average of adherence type 2 diabetes mellitus patients is $21,33 \pm 2,901$. Univariate analysis of MARS questionnaire T2DM patients had moderate adherence level of $83,3 \%$. Description of statistical adherence with characteristics can be seen in Table II.

Research from Ahmad et al.(2013) show that increasing age of adherence is getting better. Huber and Reich (2016) stated that patients age 65 to 74 tend to be twice as likely as 18-44. Rasdianah (2016) show that the patients compliance rate for $>5$ years $(55,9 \%)$ was higher than durations of sick patients $<5$ years $(39,3 \%)$.

Description of statistical distress can be seen in Table III. Based on the table, it can be seen that the mean \pm SD result of DDS questionnaire measurement based on 4 domains. Based the mean result in 4 domains can be seen that the emotional distress was the largest which $1,75 \pm 0,61$, and

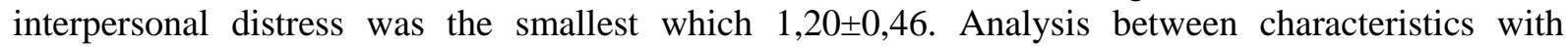
emotional distress patient in Table IV. 
Table II. Analysis between characteristics and patients adherence (MARS)

\begin{tabular}{lccc}
\hline \multicolumn{1}{c}{ Characteristics } & total & Mean \pm SD & p \\
\hline Age & 32 & $22,88 \pm 1,930$ & \\
$45-49$ & 32 & $20,16 \pm 3,293$ & $\mathbf{0 , 0 0 3} *$ \\
$50-54$ & 31 & $21,29 \pm 2,648$ & \\
$55-59$ & 31 & $21,00 \pm 2,978$ & \\
$60-65$ & & & \\
Gender & 27 & $20,44 \pm 3,401$ & 0,137 \\
Man & 99 & $21,58 \pm 2,718$ & \\
Woman & & & \\
Marital status & 7 & $21,57 \pm 3,735$ & 0,637 \\
Single/widow/divorced & 119 & $21,32 \pm 2,864$ & \\
Married & & & \\
Education & 80 & $21,15 \pm 2,904$ & 0,289 \\
Lower education & 46 & $21,65 \pm 2,900$ & \\
Higher education & & & \\
Employment & 76 & $21,01 \pm 3,109$ & 0,199 \\
$\begin{array}{l}\text { Employed } \\
\text { Unemployed }\end{array}$ & 50 & $21,82 \pm 2,505$ & \\
Income & & & \\
$<$ Rp.1000.000 & 114 & $21,22 \pm 2,935$ & 0,189 \\
$>$ Rp.1000.000 & 12 & $22,42 \pm 2,392$ & \\
duration of sick & & & \\
$<5$ years & 93 & $21,62 \pm 2,881$ & $\mathbf{0 , 0 3 8 * *}$ \\
$>$ 5 years & 33 & $20,52 \pm 2,841$ & \\
\hline *Kruskall Wallis $\boldsymbol{p}<\mathbf{0 , 0 5}$ & $* *$ Mann Whitney $\mathbf{p}<0,05$ & \\
\hline
\end{tabular}

Table III. Statistical description emotional distress based on DDS

\begin{tabular}{lc}
\hline \multicolumn{1}{c}{ Domain } & $($ mean \pm SD) \\
\hline Emosional burden & $1,75 \pm 0,61$ \\
Physician distress & $1,54 \pm 0,73$ \\
Regiment distress & $1,60 \pm 0,48$ \\
Interpersonal distress & $1,20 \pm 0,46$ \\
\hline
\end{tabular}

Bivariate analysis showed that there was significant correlation between age with physician distress $(\mathrm{p}=0.013)$, gender with emotional burden $(\mathrm{p}=0,007)$, marital status with emotional burden and interpersonal distress $(\mathrm{p}=0,034$ and $\mathrm{p}=0,018)$, duration therapy with physician distress and regiment distress $(p=0,015$ and $p=0,004)$. Analysis results between characteristics and quality of life in Table IV. 
Table IV. Analysis between characteristics and patients quality of life

\begin{tabular}{|c|c|c|c|}
\hline Characteristics & total & Mean \pm SD & $\mathbf{p}$ \\
\hline \multicolumn{4}{|l|}{ Age } \\
\hline $45-49$ & 32 & $0,764 \pm 0,113$ & 0,071 \\
\hline $50-54$ & 32 & $0,763 \pm 0,141$ & \\
\hline $55-59$ & 31 & $0,738 \pm 0,163$ & \\
\hline $60-65$ & 31 & $0,650 \pm 0,198$ & \\
\hline \multicolumn{4}{|l|}{ Gender } \\
\hline Man & 27 & $0,779 \pm 0,203$ & 0,074 \\
\hline Woman & 99 & $0,716 \pm 0,146$ & \\
\hline \multicolumn{4}{|l|}{ Marital status } \\
\hline Single/widow/divorced & 7 & $0,598 \pm 0,131$ & $\mathbf{0 , 0 3 2} *$ \\
\hline Married & 119 & $0,737 \pm 0,160$ & \\
\hline \multicolumn{4}{|l|}{ Education } \\
\hline Lower education & 80 & $0,712 \pm 0,165$ & 0,057 \\
\hline Higher education & 46 & $0,761 \pm 0,151$ & \\
\hline \multicolumn{4}{|l|}{ Employment } \\
\hline Employed & 76 & $0,751 \pm 0,166$ & 0,077 \\
\hline Unemployed & 50 & $0,696 \pm 0,149$ & \\
\hline \multicolumn{4}{|l|}{ Income } \\
\hline < Rp.1000.000 & 114 & $0,718 \pm 0,161$ & $0,013 *$ \\
\hline$>$ Rp. 1000.000 & 12 & $0,835 \pm 0,124$ & \\
\hline \multicolumn{4}{|l|}{ duration of therapy } \\
\hline$<5$ years & 93 & $0,741 \pm 0,138$ & 0,413 \\
\hline$>5$ years & 33 & $0,697 \pm 0,213$ & \\
\hline
\end{tabular}

Score obtain from EQ5D5L questionnaire converted into index to calculate quality of life indices. The EEQ5D5L index is based on the value set for the Indonesian state (Purba, et al., 2017). The average distribution value from EQ5D5L was obtained $0,71 \pm 0,16$. This is show that quality of life type 2 diabetes mellitus patients is good. Bivariate analysis showed there is significant relationship between marital status and income with quality of life. However, the number of subjects in marital status subgroup and income subgroup differ greatly so, it can affects the statistical results.

Bivariate analysis between distress and quality of life showed there is significant relationship between emotional burden with level of distress $(p=0,029)$. Analysis result between level of distress with quality of life showed in Table V. 
Table V. Analysis between distress with quality of life

\begin{tabular}{llccc}
\hline \multicolumn{1}{c}{ Domain } & $\begin{array}{c}\text { level of } \\
\text { distress }\end{array}$ & total & Mean \pm SD & p \\
\hline Emosional burden & no distress & 84 & $0,74 \pm 0,16$ & \\
& $\begin{array}{l}\text { medium } \\
\text { distres }\end{array}$ & 37 & $0,71 \pm 0,14$ & $\mathbf{0 , 0 2 9 *}$ \\
& high distress & 5 & $0,57 \pm 0,14$ & \\
Phicisian Distress & no distress & 93 & $0,73 \pm 0,17$ & \\
& medium & 25 & $0,73 \pm 0,14$ & 0,124 \\
& distres & & & \\
Regiment distress & high distress & 8 & $0,64 \pm 0,13$ & \\
& no distress & 95 & $0,74 \pm 0,16$ & \\
& medium & 29 & $0,70 \pm 0,18$ & 0,236 \\
distres & & & \\
Disterpersonal & high distress & 2 & $0,63 \pm 0,10$ & \\
& no distress & 112 & $0,73 \pm 0,16$ & \\
& medium & 12 & $0,70 \pm 0,15$ & 0,698 \\
\hline *Kruskall Wallis $<\mathbf{0 , 0 5}$ & & & \\
\hline
\end{tabular}

Multivariate analysis with linier regression between adherence, distress and quality of life have significant relationship with distress by emotional burden $(\mathrm{r}=-0,246)$ and adherence $(r=0,231)$. Coefficient determination showed 0,123, it showed that emotional burden and adherence can affect the quality of life by $17,7 \%$. Adherence will be directly proportional because it produce positive correlation which means that the higher adherence the better quality of life. Emotional burden have negative correlation which means that the lower emotional burden the better quality of life. The study of Jannoo et al. (2017) showed that adherence was significantly associated with diabetes distress ( $\mathrm{r}=-$ $0,20 ; p<0,001)$. Patients with high medication adherence levels have lower diabetes distress. Diabetes distress have significant relationship to HRQoL $(\mathrm{r}=-0,11 ; \mathrm{p}<0,001)$ indicated that patient with low grade diabetes distress will have higher quality of life. Table 6 showed analysis between adherence, distress and quality of life.

Table VI. Analysis between Adherence, Distress and Quality of Life

\begin{tabular}{lccc}
\hline \multicolumn{1}{c}{$\begin{array}{c}\text { independent } \\
\text { variable }\end{array}$} & $\begin{array}{c}\text { Coefficient } \\
\text { determination } \\
\text { (R square) }\end{array}$ & correlation & $\mathbf{p}$ \\
\hline $\begin{array}{l}\text { Emotional } \\
\text { burden } \\
\text { adherence }\end{array}$ & 0,123 & $-0,246$ & $0,000^{*}$ \\
\hline *Anova $\mathbf{p}<0,05$ & & 0,231 & \\
\hline
\end{tabular}

\section{LIMITATIONS}

The limitations of this study is the number of subjects in marital status subgroup and income subgroup differ greatly so, it can affects the statistical results. As well as the number of subjects at the distress level the number of subjects is not balanced. 


\section{CONCLUSION}

The results showed a significant association $(\mathrm{p}<0.05)$ between patient characteristics age and duration of sick with adherence. There were significant association $(p<0.05)$ between age to physician distress, gender with emotional, marital status with emotional and interpersonal distress, duration of sick to physician distress and management teraphy distress. Marital status and income had significant relationship to quality of life. Emotional burden domain had significant relationship to quality of life. Multivariate analysis showed that the relationship of adherence and distress by the emotional burden to quality of life. This study concluded the significant relationship between adherence, distress and quality of life

\section{ACKNOWLEDGEMENT}

To Puskesmas Wedarijkasa I and Trangkil and staff who have given permission and help this research activity, and all parties who have contributed in writing this scientific paper.

\section{REFERENCES}

Ahmad, N.S., Ramli, A., Islahudin, F., Paraidathathu, T., 2013, Medication adherence in patients with type 2 diabetes mellitus treated at primary healthclinics in Malaysia, Patient Preference and Adherence 2013(7): 525-530.

Horowitz, Einav, M.D., Abadi, K., Ifat, Shani, Mordechai, Shemer, Joshua, M.D., 2010, EQ-5D as a Generic Measure of Health-Related Quality if Life in Israel: Reliability, Validity and Responsiveness, Israel Medical Association Journal,12(12): 715-720.

Huber, C.A., Reich, O., 2016, Medication adherence in patients with diabetes mellitus: does physician drug dispensing enhance quality of care? Evidence from a large health claims database in Switzerland, (online) https://www.ncbi.nlm.nih.gov/pmc/articles/PMC5029845/, diakes pada 13 Maret 2018

IDF, 2012, Women and Diabetes. International Diabetes Federation (online) http://riskesdas.idf.org/women-and-diabetes, diaksespada 14 Maret 2017

Jannoo, Z., Wah, Y, B., Lazim, A, M., dan Hassali, M, A., 2017, Examining diabetes distress, medication adherence, diabetes self-care activities, diabetes-specific quality of life and healthrelated quality of life among type 2 diabetes mellitus patients, J Clin Transl Endocrinol. 2017 Sep; 9: 48-54.

Molloy, G.J., Randall, G., Wilkman, A., Perkins-Porras, L., Messerly-Burgy, N., Steptoe, A., 2012, Type D personality, self efficacy, and medication adherence following and acute coronary syndrom, Phycosom Med, 74:100-106.

Rasdianah,N.,Martodiharjo,S.,Andayani,T,M.,Hakim,L.,2016, Gambaran Kepatuhan Pengobatan Pasien Diabetes MelitusTipe 2 di Puskesmas Daerah Istimewa Yogyakarta, Jurnal Farmasi Klinik Indonesia, 5(4): 249-257

Rizkifani, S., Perwitasari D.A., dan Supadmi W., 2014, Evaluasi Kepatuhan dan Kualitas Hidup Pasien Diabetes Mellitus Tipe 2 yang Mendapatkan Monoterapi Dan Kombinasi Antidiabetik Oral-Insulin di Rumah Sakit Umum PKU Bantul, Tesis, Fakultas Farmasi, Universitas Ahmad Dahlan, Yogyakarta

Perkumpulan Endrokinologi Indonesia (Perkeni), 2015, Konsensus Pengelolaan dan Pencegahan Diabetes Mellitus Tipe 2 di Indonesia, PERKENI, Jakarta.

Permana, Y, I., 2017, Hubungan Antara Lama Sakit Dengan Tingkat Stress Pada Pasien Diabetes Melitus di RSI Surakarta, Skripsi, Fakultas Ilmu Keperawatan,Universitas Muhammadiyah Surakarta, Surakarta.

Polonsky, W.H., Fisher, L., Earles,J., Duld, R.J., Lees, J., Mullan, J., \& Jackson, R.A.,2005, Assessing Psychologycal Distress in Diabetes, Diabetes Care, 28: 626-631.

Pradana, D, L, C., 2013, Hubungan Kepuasan Terapi Diabetes dengan Kualitas Hidup Pasien Usia Lanjut Rawat Jalan di RSUP Dr. Kariadi Semarang, Tesis, Fakultas Farmasi, Universitas Gajah Mada, Yogyakarta. 
Purba,F.,Hunfeld,J.A.M., Iskandarsyah,A, Fitriana,T,S., Sadarjoen, S., Ramos-Goni, J, M., Passchier, J., Busschbach J, J, V., The Indonesian EQ5D5L Value Set, Pharmacoeconomics, Nov, 35(11):1153-1165.

Soegondo, S., 2010, Buku Panduan Penatalaksanaan Diabetes Mellitus di Layanan Kesehatan Primer di Indonesia, Departemen Ilmu Kedokteran Komunitas, 4-6 Fakultas Kedokteran Universitas Indonesia, Jakarta.

Spilker, W., dan Crammer, J.A., 1998, Quality of Life and Pharmacoeconomics An Introduction, Lippincott-Raven Publisher, Philadhelpia, New York.

World Health Organization, 2003, Adherence to Long Term Therapies, http:// http://apps.who.int/iris/bitstream/10665/42682/1/9241545992.pdf diakses 10 Nopember 2016. 